\title{
THE PERCEPTION OF COMPANY EMPLOYEES BY SMES WITH CSR CONCEPT IMPLEMENTATION
}

\author{
Zdenko Metzker \\ Faculty of Management and Economics, Tomas Bata University in Zlín, Zlín, Czech Republic \\ Email: metzker@utb.cz \\ Katarina Zvarikova \\ Faculty of Operation and Economics of Transport and Communications, University of Zilina, Zilina, Slovak \\ Republic \\ Email: katarina.zvarikova@fpedas.uniza.sk
}

Received: 26 March 2021. Revision received: 17 May 2021. Accepted: 9 June 2021

\begin{abstract}
The article aims to find out the perception of human capital issues by entrepreneurs of small and medium-sized enterprises within the V4 countries, who implement the concept of CSR in their managerial praxis. The paper is based on a questionnaire survey with data collection from September 2019 to January 2020 with a total of 1585 respondents. Statistical methods of Pearson's chi-square and z-score were used to test the hypotheses. The results revealed differences between countries in terms of employees' turnover, perception of employees as the most important corporate capital, or the implementation of participatory management style. On average, 93\% of respondents consider employees the most important company capital across the countries. There is also a strong consensus on the necessity of evaluating employee performance and motivation to innovate work practices. On the contrary, differences in the opinion on staff turnover were found among researched countries. The highest rate of turnover is among Polish entrepreneurs, and the lowest is in Hungary. With the growing company's size, the turnover of employees is getting higher. A participative management style is mainly implemented in the praxis by Slovak entrepreneurs $(90 \%)$ and least by Hungarian $(68 \%)$. However, Hungarian entrepreneurs are highly aware of the fact that their employees try to increase their performance, and healthy competition prevails among them (74\%). The results may be interesting for those who promote or implement CSR in the conditions of the researched countries.
\end{abstract}

KEYWORDS: Corporate social responsibility, CSR impact on employees, small and medium-sized enterprises, business environment in the V4 countries, V4 SMEs segment

JEL CLASSIFICATION: L11, L20, L26, L53, M14

Reference: Metzker, Z., Zvarikova, K. (2021). The Perception of Company Employees by SMEs with CSR Concept Implementation. International Journal of Entrepreneurial Knowledge, 9(1), 81-96. doi: 10.37335/ijek.v9i1.128

\section{INTRODUCTION}

Nowadays, at a time of increased pressure to take responsibility for social and environmental issues, there is an increasing emphasis on the corporate social responsibility concept (hereinafter referred to as CSR) and its implementation. Many researchers deal with social responsibility, but their main focus is on large companies because they represent the largest number of companies involved in CSR. SMEs have a relatively small economic power, but on the other hand, they are considered as one of the main engines of the economy, with a positive effect on employment, gross domestic product, and state income (Kljucnikov et al., 2016). SMEs also predominate in the subsector of essential strategic business services. This caused an increasing trend of large companies to use SMEs in the form of outsourcing (Rocha, 2012). CSR practices are seen as potential tools that can be applied even for the SME segment (Belas $e t$ al., 2020). But as it is claimed by Jorge et al. (2016), it is not possible to implement the CSR concept and methodology used by large companies to the "specific reality" of SMEs without previous consideration 


\section{INTERNATIONAL JOURNAL OF ENTREPRENEURIAL KNOWLEDGE}

Issue 1, volume 9, ISSN 2336-2960 (Online)

www.ijek.org

of these specific conditions. So the tools that SMEs need to cope with in the implementation of CSR will be different from the previously formalized tools used by larger companies (Gelbman, 2010).

If companies decide to adopt the concept of CSR and apply it to business practice, it is a long-term process. Companies are aware of the benefits of the CSR idea. It is proven that the implementation of CSR has a positive effect on product perception, brand loyalty, and image of the company, and CSR can be used as an effective tool how to differentiate products from the other competitors and increase the competitive advantage of the company (Lu et al., 2020; Bardos et al., 2020). Despite these competitive benefits of CSR implementation, according to Boccia et al. (2019), price still remains the key criterion in most of the customers' decision-making. The implementation of CSR has a positive effect on the attitudes and behaviour of employees (Wang et al., 2020), identification of the employee with the company, his perception of involvement in meaningful activities, and motivation to work more (Breger et al., 2020) or lower employee's turnover (Vveinhardt \& Sroka, 2020) while we must not forget, that even in the age of automation, the human factor remains still irreplaceable (Lazanyi et al., 2020). From the managerial point of view, it is of particular interest to investigate the influence of CSR on sustainability or continuance of the activity (Dayanandan et al., 2018).

The presented work examines, in the context of the Visegrad fourth countries, how the medium-sized enterprises (SMEs) managers/owners, who implemented CSR into their company's praxis, perceive their employees. Data were obtained through a comprehensive questionnaire survey, which was focused on management, business risks, and the decline of small and medium-sized enterprises. The survey was realized from September 2019 to January 2020. The structure of the article is the following: the theoretical part presents the results of the literature review in the field of CSR in the international context, which could be confronted with the authors' results. The next part of the article presents the aim of the work, methodology, and scientific hypotheses. In the results section, not only findings of the study are presented but these findings are also compared with the results of other studies. In last part of the papers, the basic results of the research are formulated, including the limitations of the research.

\section{THEORETICAL BACKGROUND}

The European Commission (2011) defines CSR as the responsibility of companies for their impact on society. Enterpreneurs should integrate social, environmental, ethical, consumer, and human rights aspects into their businesses, and core strategy in cooperation with stakeholders to maximize creating common values for owners / shareholders, other stakeholders and society, and also identify, prevent, and mitigate their possible adverse effects.

Archie B. Carrol (2016) considers CSR as a concept of philanthropy, ethics, legal and economic areas of business-society relations. Economic responsibility - creating added value - brings benefits to all stakeholders. Legal responsibility - compliance with regulations and laws. Ethical responsibility - it is expected that companies do what is right and fair for society - organizations adopt the activities, standards, and practices that are expected, even if they are not clearly defined by law. Corporate philanthropy represents a company's participation in activities, which are not expected to do, to do business ethically - what is right for the whole society. Corporate philanthropy is identified by Zeng et al. (2020) as a significant factor for customers and on the other hand as less relevant factors are consider ethical responsibility to consumers and employees. Another definition of CSR is provided by the OECD (2001) which states the basic elements of CSR as a business investment - providing jobs, ensuring the production of goods, and services to meet consumer needs and work to bring companies the overall well-being and improve the living standards of the population - thus providing better returns to their shareholders / owners. Nowadays, Chojnacka \& Wiśniewska (2016) claim that there is no generally accepted definition of corporate social responsibility. Based on many definitions, the concept of CSR can be understood as a 


\section{INTERNATIONAL JOURNAL OF ENTREPRENEURIAL KNOWLEDGE}

Issue 1, volume 9, ISSN 2336-2960 (Online)

www.ijek.org

balanced style of management between asset and risk management, taking into account the benefits of all stakeholders (Hadj, Omri, Al-Tit, 2020). It refers to a business system that enables the production and distribution of wealth for the betterment of stakeholders through the implementation and integration of ethical systems and sustainable management practices (Godfrey, 2016). CSR implementation is useful for businesses to mitigate the negative effects of enterprise's activities on the environment (Bikefe et al., 2020), it could contribute to a better image of the company (Barakat et al., 2016) or even to get over negative word-of-mouth (Alhouti et al., 2021, Kang et al., 2021). Through CSR, the companies strive for a positive impact on the labor, social and natural environment and thus gain a competitive advantage and ensure long-term sustainability (Stojanovic et al., 2020).

CSR implementation is more than just a trend (Thao et al., 2019 and Stojanovic et al., 2020). Nowadays, according to some authors, it is necessary to ensure sustainable development. Through the implementation of CRS, the companies could build their prestige, improve satisfaction and loyalty of stakeholders, thus increase the value of the company, and CSR is the key factor in showing the environmental or charitable activities (Gorgenyi-Hegyes \& Fekete Farkas 2019). But despite of these statements, according to Jorge et al. (2016), there is still a lot of SMEs managers who do not implement the CSR concept because they are not informed about CSR practices or they do not know how they should implement CSR in their practices.

The following benefits can be achieved through CSR's implementation: increasing of the intangible assets of the organization (image, reputation, brand value,...) (Lee, 2016; Walker et al., 2017); cost savings - CSR activities lead to innovations reducing explicit costs (Du et al., 2010; Marques Lourenço \& de Sousa-Filho, 2020); increasing profits; quality and satisfied loyal customers (Yumei et al., 2021; Stojanovic et al., 2020; Chen et al., 2019; Lu et al.. 2019; Alhouti et al., 2021); gaining a competitive advantage (Gorgenyi-Hegyes \& Fekete Farkas, 2019; Walker et al., 2017; Bacinello et al., 2020), increasing of the product market perception - this statement is stronger in the competitive industries and for standardized goods (Bardos et al., 2020) or customer loyalty (Lourenço \& de Sousa-Filho, 2020); attracting investors (Du et al., 2010; Belás et al., 2020; Stojanovic et al., 2020) and many others advantages. Using various CSR activities, SMEs also offer potential employees benefits that ensure their interest and subsequent loyalty (Stojanovic et al. 2020; Brieger et al., 2020). CSR also influences companies in the choice of business partners in suppliercustomer relationships (Ali et al. 2020).

Although SMEs reflect a considerable share in the economic activity, many of the studies are focused on large firms only. According to Habek (2017), CSR is a relatively new concept in the V4 countries, but it is expanding rapidly, especially through multinational companies. Some CSR issues are focused on community, corporate governance, public - private partnerships, and prosperity. The most common reasons, why companies do not implement CSR in V4 countries are: lack of employees with relevant knowledge in this area, lack of information or benefits from the government, or lack of company's financial resources (Zelazna et al., 2020; Nagypál, 2014; Slabá, 2020; Lušňáková et al., 2019).

Li et al. (2020) highlighted that most of the studies are focused on companies' financial performance. From the employees' point of view (as employees are considered as one of the most important stakeholders), Flammer and Luo (2017) suggest that improving a company's social responsibility brings the following benefits: improving employee performance and helping to manage adverse employee behavior. According to Reicher (2019) implementing of CSR concept has a positive impact on the improvement of workplace morale. Galvas found a positive impact on implementation and enforcement of CSR in the company in the context of employee engagement (Galvas, 2016) and Rupp et al. (2018) also provide that not only on engagement but also on employees' health and organizational productivity. The positive nature of CSR in the context of the company's employees is also confirmed by a study by Brieger et al. (2020), who state if a company is socially responsible, it contributes to better identification of the employee with the company, and thus the employee has a greater motivation to work more. 


\section{INTERNATIONAL JOURNAL OF ENTREPRENEURIAL KNOWLEDGE}

Issue 1, volume 9, ISSN 2336-2960 (Online)

www.ijek.org

However, the authors point out that this aspect can indirectly lead to workaholism. Vveinhardt \& Sroka (2020) analysed CSR as a useful tool for reducing employee turnover in the company. They confirm an impact of CSR's implementation on the better position of employees and their lower turnover. This research was not conducted from the managers / business owners' point of view but the employees' perspective. Nazir and U1 Islam (2020), in addition to confirming CSR's contribution to employee engagement, found that CSR implementation creates better workplace environment where employees prefer collective gain over anindividual. Farrukh et al. (2019) extended the knowledge of the positive effect of CSR on the employees' engagement from the gender point of view and found out that this positive effect of CSR is higher for women compared to men. CSR activities also significantly affect employees' loyalty. At the same time, the results confirmed that the employee's loyalty is higher, which has the positive impact on the company's performance and competitiveness (Stojanovic et al., 2020; Ali et al., 2020; Jia et al., 2019). Chen \& Khuangga (2020) add that fair working conditions achieved through CSR implementations contribute to higher employee performance.

Liu et al. (2020) found a positive impact between the implementation of CSR in the company and the level of innovation by employees. Another part of the study revealed a positive relationship between employee-oriented CSR in the company and innovation, resp. their efficiency, caused by stronger employment stability (lower turnover). Li et al. (2020) also revealed in their research that through CSR the companies are able to promote employee creativity and help employees to foster their innovative behavior what could increase their job satisfaction and improve their participation in the activities of the company. It is, therefore, appropriate to point out the positive impact of CSR on employees.

\section{AIM AND METHODOLOGICAL BASES}

The aim of the paper is to present the perception of employees by managers of small and medium-sized enterprises in the V4 countries, who implement the concept of CSR in their practice. The article examines the attributes of the perception of employees by these entrepreneurs from the geographical point of view - by comparing individual V4 countries and from the company's size aspect - small enterprise (up to 49 employees) and medium enterprise (50-249 employees).

The questionnaire survey of small and medium-sized enterprises involved 454 Czech, 368 Slovak, 364 Polish, and 399 Hungarian representatives of managers / owners. Data collection took place from September 2019 to April 2020 in the V4 countries (CR, SR, PL, HU). The purposive sample was as follows: 8250 SMEs in Czechia, 10100 SMEs in Slovakia, 7680 Polish SMEs, and 8750 SMEs in Hungary. The average rate of return for the questionnaires was as followed: Czechia 3,6\%; Slovakia 5,5\%, Poland: 4,7\%, Hungary 4,6\%. The description of respondents sample is divided into individual V4 countries:

\section{Czech Republic}

- enterprise size: 290 (63.9\%) micro enterprise (up to 9 employees), 107 (23.6\%) small enterprise (from 10 to 49 employees), 57 (12.5\%) medium enterprise (from 50 to 249 employees);

- period of doing business: 27 (5.9\%) up to 3 years, 28 (6.2\%) from 3 to 5 years, 64 (14.1\%) from 6 to 10 years, $335(73.8 \%)$ more than 10 years;

- respondent's gender: 323 male (71,1\%), 131 (28,9\%) female;

- respondent's age: $69(15,2 \%)$ up to 35 years, $106(23,3 \%)$ from 36 to 45 years, $122(26,9 \%)$ from 46 to 55 years, $157(34,6 \%)$ more than 56 years; 
INTERNATIONAL JOURNAL OF ENTREPRENEURIAL KNOWLEDGE

Issue 1, volume 9, ISSN 2336-2960 (Online)

www.ijek.org

\section{Slovak Republic}

- enterprise size: $216(58.7 \%)$ micro enterprise (up to 9 employees), 106 (28.8\%) small enterprise (from 10 to 49 employees), 46 (12.5\%) medium enterprise (from 50 to 249 employees);

- period of doing business: $23(6.2 \%)$ up to 3 years, 30 (8.2\%) from 3 - 5 years, 52 (14.1\%) from 6 - 10 years, $263(71.5 \%)$ more than 10 years;

- respondent's gender: 253 male (68,8\%), 115 (31,2\%) female;

- respondent's age: $66(17,9 \%)$ up to 35 years, 79 (21,5\%) from 36 to 45 years, 106 (28,8\%) from 46 to 55 years, $117(31,8 \%)$ more than 56 years;

\section{Poland}

- enterprise size: 202 (55.5\%) micro-enterprise (up to 9 employees), 85 (23.3\%) small enterprise (from 10 to 49 employees), 77 (21.2\%) medium-sized enterprise (from 50 to 249 employees);

- period of doing business: $46(12.6 \%)$ up to 3 years, 47 (12.9\%) from 3 to 5 years, 72 (19.8\%) from 6 to 10 years, $199(54.7 \%)$ more than 10 years;

- respondent's gender: 230 male (63,2\%), 134 (36,8\%) female;

- respondent's age: $115(31,6 \%)$ up to 35 years, 159 (43,7\%) from 36 to 45 years, $90(24,7 \%)$ from 46 to 55 years, $0(0,0 \%)$ more than 56 years;

\section{Hungary}

- enterprise size: 268 (67.2\%) micro-enterprise (up to 9 employees), 73 (18.3\%) small enterprise (from 10 to 49 employees), 58 (14.5\%) medium-sized enterprise (from 50 to 249 employees);

- period of doing business: 51 (12.8\%) up to 3 years, 34 (8.5\%) from 3 to 5 years, 62 (15.5\%) from 6 to 10 years, $252(63.2 \%)$ more than 10 years;

- respondent's gender: 275 male (68,9\%), 124 (31,1\%) female;

- respondent's age: $62(15,5 \%)$ up to 35 years, 131 (32,8\%) from 36 to 45 years, 134 (33,6\%) from 46 to 55 years, $72(18,1 \%)$ more than 56 years;

The research is focused on the entrepreneurs who agreed with the concept of CSR and who had implemented it in their managerial practice (consensus answers to statements X1 to X5). These papers are focused on their attitudes to statements in employees' relations (T1 to T5).

- X1: The owner (manager) should take into account the moral and ethical implications of his decisions.

- X2: I know the concept of corporate social responsibility (CSR) and promote it in my managerial work.

- X3: CSR implementation allows our company to gain a competitive advantage in the market and higher customer loyalty.

- X4: CSR enables our company to gain a good reputation and new business opportunities.

- X5: CSR enables our company to acquire satisfied, loyal and motivated employees.

- T1: I consider human capital in the company as the most important one.

- T2: The business owner (manager) should regularly evaluate the performance of their subordinates and motivate them to innovate workflows.

- T3: Employee turnover is low and has no negative impact on my business.

- T4: I apply a participative management style (involving employees in decision making).

- T5: Our employees strive to improve their performance and competition among them prevails. 
INTERNATIONAL JOURNAL OF ENTREPRENEURIAL KNOWLEDGE

Issue 1, volume 9, ISSN 2336-2960 (Online)

www.ijek.org

Respondents were allowed to answer as follows (Likert scale): strongly agree, agree, disinterested, disagree, strongly disagree.

Based on the segmentation of respondents into a selected group, which agreed with the statements X1 to X4 - specifically the positive approach of CSR and its implementation in the company, the sample of respondents was adjusted as follows:

\section{Czech Republic}

- enterprise size: total 81 enterprises: 46 (56,8\%) micro (up to 9 employees), 25 (30.9\%) small enterprise (from 10 to 49 employees), 10 (12.3\%) medium-sized enterprise (from 50 to 249 employees);

- period of doing business: $6(7.4 \%)$ up to 3 years, 3 (3.7\%) from 3 to 5 years, 10 (12.3\%) from 6 to 10 years, $62(76.6 \%)$ more than 10 years;

- respondent's gender: 57 male (70,4\%), 24 (29,6\%) female;

- respondent's age: $12(14,8 \%)$ up to 35 years, 15 (18,5\%) from 36 to 45 years, 25 (30,9\%) from 46 to 55 years, $29(35,8 \%)$ more than 55 years;

\section{Slovak Republic}

- enterprise size: total 80 enterprises: 43 (53,7\%) micro (up to 9 employees), 27 (33,7\%) small enterprise (from 10 do 49 employee), 10 (12,6\%) medium-sized enterprises (from 50 to 249 employees);

- period of doing business: 8 (10,0 \%) up to 3 years, 7 (8.8\%) from 3 to 5 years, 10 (12.5\%) from 6 to 10 years, $55(68.7 \%)$ more than 10 years;

- respondent's gender: 44 male (55,0\%), 36 (45,0\%) female;

- respondent's age: 18 (22,5\%) up to 35 years, 13 (16,3\%) from 36 to 45 years, 19 (23,7\%) from 46 to 55 years, $30(37,5 \%)$ more than 55 years;

\section{Poland}

- enterprise size: total 111 enterprises: 61 (55.5\%) micro-enterprise (up to 9 employees), 25 (22.5\%) small enterprise (from 10 to 49 employees), 25 (22.5\%) medium-sized enterprise (from 50 to 249 employees);

- period of doing business: 14 (12.6\%) up to 3 years, 13 (11.7\%) from 3 to 5 years, 21 (18.9\%) from 6 to 10 years, $63(56.8 \%)$ more than 10 years;

- respondent's gender: 67 male (60,4\%), 44 (39,6\%) female;

- respondent's age: $39(35,1 \%)$ up to 35 years, $52(46.9 \%)$ age from 36 to 45 years, $20(18.0 \%)$ age from 46 to 55 years, $0(0.0 \%)$ more than 56 years;

\section{Hungary}

- enterprise size: total 147 enterprises: 93 (63.3\%) micro-enterprise (up to 9 employees), 0 (0.0\%) small enterprise (from 10 to 49 employees), 54 (36.7\%) medium-sized enterprise (from 50 to 249 employees);

- period of doing business: 19 (12,9\%) up to 3 years, 15 (10.2\%) from 3 - 5 years, 19 (12.9\%) from 6 - 10 years, $94(64.0 \%)$ more than 10 years;

- respondent's gender: 90 male (61,2\%), 57 (38,8\%) female; 
INTERNATIONAL JOURNAL OF ENTREPRENEURIAL KNOWLEDGE

Issue 1, volume 9, ISSN 2336-2960 (Online)

www.ijek.org

- respondent's age: $22(15,0 \%)$ up to 35 years, $43(29.3 \%)$ from 36 to 45 years, 54 (36.7\%) from 46 to 55 years, 28 (19.0) more than 56 years;

Statistical methods as Pearson's Chi-square test and Z-score were applied to determine statistically significant differences between selected groups of respondents according to selected criteria (Meloun \& Militky, 2012).

The following hypotheses were defined in the research:

- H1a: there are statistically significant differences in the attitudes of managers using the concept of CSR in their practice towards T1 depending on the country

- H1b: there are statistically significant differences in the attitudes of managers using the concept of CSR in their practice towards T1 depending on the size of the company

- H2a: there are statistically significant differences in the attitudes of managers using the concept of CSR in their practice towards T2 depending on the country

- H2b: there are statistically significant differences in the attitudes of managers using the concept of CSR in their practice towards T2 depending on the size of the company

- H3a: there are statistically significant differences in the attitudes of managers using the concept of CSR in their practice towards T3 depending on the country

- H3b: there are statistically significant differences in the attitudes of managers using the concept of CSR in their practice towards T3 depending on the size of the company

- H4a: there are statistically significant differences in the attitudes of managers using the concept of CSR in their practice towards T4 depending on the country

- H4b: there are statistically significant differences in the attitudes of managers using the concept of CSR in their practice towards T4 depending on the size of the company

- H5a: there are statistically significant differences in the attitudes of managers using the concept of CSR in their practice towards T5 depending on the country

- H5b: there are statistically significant differences in the attitudes of managers using the concept of CSR in their practice towards T5 depending on the size of the company

\section{RESULTS AND DISCUSSION}

Table 1 "I consider human capital in the company as the most important one." - the structure of answers depending on the country

\begin{tabular}{|c|c|c|c|c|c|c|c|c|c|c|}
\hline \multirow{3}{*}{ strongly agree + agree } & \multicolumn{2}{|c|}{ CZ 81} & \multicolumn{2}{|c|}{ SK 80} & \multicolumn{2}{|c|}{ PL 111} & \multicolumn{2}{|c|}{ HU 147} & \multirow{2}{*}{ Z-score } & \multirow{2}{*}{$\begin{array}{l}\text { Z-score } \\
\text { p-value }\end{array}$} \\
\hline & No. & $\%$ & No. & $\%$ & No. & $\%$ & No. & $\%$ & & \\
\hline & 77 & 95,06 & 74 & 92,50 & 103 & 92,79 & 123 & 83,67 & $\mathrm{CZ} / \mathrm{SK}$ & 0.5029 \\
\hline disinterested & 2 & 2,47 & 6 & 7,50 & 7 & 6,31 & 16 & 10,88 & $\mathrm{CZ} / \mathrm{PL}$ & 0.5222 \\
\hline $\begin{array}{c}\text { disagree }+ \text { strongly } \\
\text { disagree }\end{array}$ & & 2,47 & 0 & 0,00 & 1 & 0,90 & 8 & 5,44 & $\mathrm{CZ} / \mathrm{HU}$ & 0.0121 \\
\hline$\chi$-quadrat & \multicolumn{2}{|c|}{10,3386} & & & & & \multirow{2}{*}{\multicolumn{2}{|c|}{$\begin{array}{l}\text { CZ - Czech Republic } \\
\text { SK - Slovak Republic }\end{array}$}} & \multirow{2}{*}{\multicolumn{2}{|c|}{$\begin{array}{l}\text { PL }- \text { Poland } \\
\text { HU - Hungary } \\
a=0.05\end{array}$}} \\
\hline$\chi$-quadrat $p$-value & \multicolumn{2}{|c|}{0,0159} & & & & & & & & \\
\hline
\end{tabular}

(Source: own data collection)

To a large extent, entrepreneurs implementing the concept of CSR in their company practice strongly agree that employees are the most important capital of the company. It was recorded the lowest values in the case of Hungarian entrepreneurs, where in general, there is statistical significance between 
Hungarian and Czech entrepreneurs. The Pearson's chi-square values demonstrate statistical significance between countries. There is a difference in the claim that there are statistically significant differences in the attitudes of managers using the concept of CSR in their practice towards the importance of human capital depending on the country. The hypothesis H1a was accepted.

Table 2 "I consider human capital in the company as the most important one." - the structure of answers depending on the size of the company

\begin{tabular}{|c|c|c|c|c|c|c|c|c|c|}
\hline & \multicolumn{2}{|c|}{ MICRO 243} & \multicolumn{2}{|c|}{ SMALL 77} & \multicolumn{2}{|c|}{ MEDIUM 99} & \multirow{2}{*}{\multicolumn{2}{|c|}{ Z-score }} & \multirow{2}{*}{$\begin{array}{l}\text { Z-score } \\
\text { p-value }\end{array}$} \\
\hline & No. & $\%$ & No. & $\%$ & No. & $\%$ & & & \\
\hline strongly agree + agree & 216 & 93,31 & 74 & 96,10 & 87 & 87,88 & \multirow{3}{*}{$\mathrm{MS} / \mathrm{ME}$} & 0.7951 & 0.4237 \\
\hline disinterested & 19 & 8,12 & 3 & 3,90 & 9 & 9,09 & & -0.7361 & 0.4593 \\
\hline disagree + strongly disagree & 8 & 3,42 & 0 & 0,00 & 3 & 3,03 & & -0.2884 & 0.7718 \\
\hline$\chi$-quadrat & \multicolumn{2}{|c|}{0.6462} & \multirow{2}{*}{\multicolumn{7}{|c|}{$\begin{array}{l}\text { MS - micro and small sized enterprises } \\
\text { ME - medium sized enterprises }\end{array}$}} \\
\hline$\chi$-quadrat p-value & \multicolumn{2}{|c|}{0.7239} & & & & & & & \\
\hline
\end{tabular}

(Source: own data collection)

In terms of the size of the company, it was not noticed that entrepreneurs implementing the concept of CSR in their management practise have significant differences in their claims. The H1b hypothesis was rejected.

Table 3 "The business owner (manager) should regularly evaluate the performance of their subordinates and motivate them to innovate workflows." - the structure of answers depending on the country

\begin{tabular}{|c|c|c|c|c|c|c|c|c|c|c|}
\hline \multirow{3}{*}{ strongly agree + agree } & \multicolumn{2}{|c|}{ CZ 81} & \multicolumn{2}{|c|}{ SK 80} & \multicolumn{2}{|c|}{ PL 111} & \multicolumn{2}{|c|}{ HU 147} & \multirow{2}{*}{ Z-score } & \multirow{2}{*}{$\begin{array}{l}\text { Z-score } \\
\text { p-value }\end{array}$} \\
\hline & No. & $\%$ & No. & $\%$ & No. & $\%$ & No. & $\%$ & & \\
\hline & 77 & 95,06 & 79 & 98,75 & 106 & 95,05 & 141 & 95,92 & $\begin{array}{ll}\mathrm{CZ} / \mathrm{SK} & -1.3489 \\
\end{array}$ & 0.1770 \\
\hline disinterested & 2 & 2,47 & 1 & 1,25 & 4 & 3,60 & 6 & 4,08 & $\begin{array}{ll}\mathrm{CZ} / \mathrm{PL} & -0.1404 \\
\end{array}$ & 0.8887 \\
\hline $\begin{array}{c}\text { disagree }+ \text { strongly } \\
\text { disagree }\end{array}$ & & 2,47 & 0 & 0,00 & 1 & 0,90 & 0 & 0,00 & $\mathrm{CZ} / \mathrm{HU} \quad-0.3023$ & 0.7642 \\
\hline$\chi$-quadrat & \multicolumn{2}{|c|}{1,8835} & & & & & \multirow{2}{*}{\multicolumn{2}{|c|}{$\begin{array}{l}\text { CZ - Czech Republic } \\
\text { SK - Slovak Republic }\end{array}$}} & \multirow{2}{*}{\multicolumn{2}{|c|}{$\begin{array}{l}\text { PL }- \text { Poland } \\
\text { HU }- \text { Hungary } \\
a=0.05\end{array}$}} \\
\hline$\chi$-quadrat p-value & \multicolumn{2}{|c|}{0,5969} & & & & & & & & \\
\hline
\end{tabular}

(Source: own data collection)

Table 4 "The business owner (manager) should regularly evaluate the performance of their subordinates and motivate them to innovate workflows." - the structure of answers to depending on the size of the company

\begin{tabular}{|c|c|c|c|c|c|c|c|c|c|}
\hline & \multicolumn{2}{|c|}{ MICRO 243} & \multicolumn{2}{|c|}{ SMALL 77} & \multicolumn{2}{|c|}{ MEDIUM 99} & \multirow{2}{*}{\multicolumn{2}{|c|}{ Z-score }} & \multirow{2}{*}{$\begin{array}{l}\text { Z-score } \\
\text { p-value }\end{array}$} \\
\hline & No. & $\%$ & No. & $\%$ & No. & $\%$ & & & \\
\hline strongly agree + agree & 231 & 98,72 & 75 & 97,40 & 97 & 97,98 & \multirow{3}{*}{$\mathrm{MS} / \mathrm{ME}$} & -1.0684 & 0.2846 \\
\hline disinterested & 10 & 4,27 & 1 & 1,30 & 2 & 2,02 & & 0.7108 & 0.4777 \\
\hline disagree + strongly disagree & 2 & 0,85 & 1 & 1,30 & 0 & 0,00 & & 09669 & 0.3320 \\
\hline$\chi$-quadrat & \multicolumn{2}{|c|}{0.5079} & \multirow{2}{*}{\multicolumn{7}{|c|}{$\begin{array}{l}\text { MS - micro and small sized enterprises } \\
\text { ME - medium sized enterprises }\end{array}$}} \\
\hline$\chi$-quadrat p-value & \multicolumn{2}{|c|}{0.7757} & & & & & & & \\
\hline
\end{tabular}


INTERNATIONAL JOURNAL OF ENTREPRENEURIAL KNOWLEDGE

Issue 1, volume 9, ISSN 2336-2960 (Online)

www.ijek.org

(Source: own data collection)

Managers / business owners strongly agreed that employee performance should be assessed and they motivate them to innovate in work practices. It was not observed any significant differences between the V4 countries. This is also applied to comparisons in terms of company size. Therefore, we reject the hypotheses related to this statement $(\mathrm{H} 2 \mathrm{a}$ and $\mathrm{H} 2 \mathrm{~b})$ - there are no statistically significant differences in the statement, that employee performance should be assessed and managers / owners motivate employees to innovate in work practices.

Table 5 "Employee turnover is low and has no negative impact on my business." - the structure of answers depending on the country

\begin{tabular}{|c|c|c|c|c|c|c|c|c|c|c|}
\hline & \multicolumn{2}{|c|}{ CZ 81} & \multicolumn{2}{|c|}{ SK 80} & \multicolumn{2}{|c|}{ PL 111} & \multicolumn{2}{|c|}{ HU 147} & \multirow{2}{*}{ Z-score } & \multirow{2}{*}{$\begin{array}{l}\text { Z-score } \\
\text { p-value }\end{array}$} \\
\hline & No. & $\%$ & No. & $\%$ & No. & $\%$ & No. & $\%$ & & \\
\hline strongly agree + agree & 53 & 65,43 & 55 & 68,75 & 80 & 72,07 & 91 & 61,90 & $\mathrm{CZ} / \mathrm{SK}$ & 0.6527 \\
\hline disinterested & 16 & 19,75 & 15 & 18,75 & 15 & 13,51 & 41 & 27,89 & $\begin{array}{ll}\mathrm{CZ} / \mathrm{PL} & -0.9848 \\
\end{array}$ & 0.3271 \\
\hline $\begin{array}{c}\text { disagree }+ \text { strongly } \\
\text { disagree }\end{array}$ & 12 & 14,81 & 10 & 12,50 & 16 & 14,41 & 15 & 10,20 & $\mathrm{CZ} / \mathrm{HU}$ & 0.5961 \\
\hline$\chi$-quadrat & \multicolumn{2}{|c|}{8,9306} & & & & & \multirow{2}{*}{\multicolumn{2}{|c|}{$\begin{array}{l}\text { CZ - Czech Republic } \\
\text { SK - Slovak Republic }\end{array}$}} & \multirow{2}{*}{\multicolumn{2}{|c|}{$\begin{array}{l}\text { PL - Poland } \\
\text { HU - Hungary } \\
a=0.05\end{array}$}} \\
\hline$\chi$-quadrat p-value & \multicolumn{2}{|c|}{0,1775} & & & & & & & & \\
\hline
\end{tabular}

(Source: own data collection)

The statement of low employee turnover was least agreed by entrepreneurs in Hungary. However, entrepreneurs in Poland had the most positive answers. On average, more than $2 / 3$ of the surveyed entrepreneurs did not observe high employee turnover. However, Czech entrepreneurs did not agree with this statement the most. Despite this, our research did not show statistically significant deviations in the context of respondents' domicile. The hypothesis H3a was rejected.

Table 6 "Employee turnover is low and has no negative impact on my business." - the structure of answers depending on the size of the company

\begin{tabular}{|c|c|c|c|c|c|c|c|c|c|}
\hline & \multicolumn{2}{|c|}{ MICRO 243} & \multicolumn{2}{|c|}{ SMALL 77} & \multicolumn{2}{|c|}{ MEDIUM 99} & \multirow{2}{*}{\multicolumn{2}{|c|}{ Z-score }} & \multirow{2}{*}{$\begin{array}{l}\text { Z-score } \\
\text { p-value }\end{array}$} \\
\hline & No. & $\%$ & No. & $\%$ & No. & $\%$ & & & \\
\hline strongly agree + agree & 170 & 72,65 & 51 & 66,23 & 58 & 58,59 & \multirow{3}{*}{ MS/ME } & 1.9313 & 0.0536 \\
\hline disinterested & 51 & 21,79 & 15 & 19,48 & 21 & 21,21 & & -0.1259 & 0.8966 \\
\hline disagree + strongly disagree & 22 & 9,40 & 11 & 14,29 & 20 & 20,20 & & -2.5870 & 0.0096 \\
\hline$\chi$-quadrat & \multicolumn{2}{|c|}{7.1049} & \multirow{2}{*}{\multicolumn{5}{|c|}{$\begin{array}{l}\text { MS - micro and small sized enterprises } \\
\text { ME - medium sized enterprises }\end{array}$}} & \multirow{2}{*}{$a=0.05$} & \\
\hline$\chi$-quadrat $p$-value & \multicolumn{2}{|c|}{0.0287} & & & & & & & \\
\hline
\end{tabular}

(Source: own data collection)

On the other hand, when comparing companies in terms of size, it was noticed the lowest employee turnover in micro-enterprises (up to $73 \%$ of surveyed managers agree with low employee turnover, on the contrary to only $9 \%$ of surveyed micro-enterprise managers who did not agree with this statement). In this case, we accept hypothesis $\mathrm{H} 3 \mathrm{~b}$ - there is a statistical significance in the answers to the question of employee turnover in the context of company size. From the results it could be confirmed that the smallest employee turnover in companies, which implement the concept of CSR in their practice, is seen 
INTERNATIONAL JOURNAL OF ENTREPRENEURIAL KNOWLEDGE

Issue 1, volume 9, ISSN 2336-2960 (Online)

www.ijek.org

in micro-enterprises, followed by small and medium-sized enterprises. Following from this knowledge it could be stated a negative correlation in the size of the company - if the company is larger in terms of the number of employees than their employee turnover is higher.

\begin{tabular}{|c|c|c|c|c|c|c|c|c|c|c|}
\hline & \multicolumn{2}{|c|}{ CZ 81} & \multicolumn{2}{|c|}{ SK 80} & \multicolumn{2}{|c|}{ PL 111} & \multicolumn{2}{|c|}{ HU 147} & \multirow{2}{*}{ Z-score } & \multirow{2}{*}{$\begin{array}{l}\text { Z-score } \\
\text { p-value }\end{array}$} \\
\hline & No. & $\%$ & No. & $\%$ & No. & $\%$ & No. & $\%$ & & \\
\hline strongly agree + agree & 71 & 87,66 & 72 & 90,00 & 85 & 76,58 & 100 & 68,03 & $\mathrm{CZ} / \mathrm{SK}$ & 0.6384 \\
\hline disinterested & 7 & 8,64 & 4 & 5,00 & 17 & 15,32 & 18 & 12,24 & $\mathrm{CZ} / \mathrm{PL}$ & 0.0524 \\
\hline $\begin{array}{c}\text { disagree }+ \text { strongly } \\
\text { disagree }\end{array}$ & 3 & 3,70 & 4 & 5,00 & 9 & 8,11 & 29 & 19,73 & $\mathrm{CZ} / \mathrm{HU}$ & 0.0010 \\
\hline \multirow{2}{*}{$\begin{array}{c}\chi \text {-quadrat } \\
\chi \text {-quadrat p-value }\end{array}$} & \multicolumn{2}{|c|}{27,4129} & & & & & \multirow{2}{*}{\multicolumn{2}{|c|}{$\begin{array}{l}\text { CZ - Czech Republic } \\
\text { SK - Slovak Republic }\end{array}$}} & \multirow{2}{*}{\multicolumn{2}{|c|}{$\begin{array}{l}\text { PL - Poland } \\
\text { HU - Hungary } \\
a=0.05\end{array}$}} \\
\hline & \multicolumn{2}{|c|}{0,0001} & & & & & & & & \\
\hline
\end{tabular}

Table 7 "I apply a participative management style (involving employees in decision making)." the structure of answers depending on the country

(Source: own data collection)

When the enterprises are segmented according to individual V4 countries, the participatory style of management is mostly implemented in Slovakia. On the contrary, it is least implemented by entrepreneurs in Hungary. Results point out statistically significant differences in the overall responses to the applying of participatory management style. Hypothesis H4a was accepted.

Table 8 "I apply a participative management style (involving employees in decision making)." the structure of answers depending on the size of the company

\begin{tabular}{|c|c|c|c|c|c|c|c|c|c|}
\hline & \multicolumn{2}{|c|}{ MICRO 243} & \multicolumn{2}{|c|}{ SMALL 77} & \multicolumn{2}{|c|}{ MEDIUM 99} & \multirow{2}{*}{\multicolumn{2}{|c|}{ Z-score }} & \multirow{2}{*}{$\begin{array}{l}\text { Z-score } \\
\text { p-value }\end{array}$} \\
\hline & No. & $\%$ & No. & $\%$ & No. & $\%$ & & & \\
\hline strongly agree + agree & 173 & 73,93 & 70 & 90,91 & 85 & 85,86 & \multirow{3}{*}{$\mathrm{MS} / \mathrm{ME}$} & -2.0922 & 0.0366 \\
\hline disinterested & 31 & 13,25 & 5 & 6,49 & 10 & 10,10 & & 0.3196 & 0.7490 \\
\hline disagree + strongly disagree & 39 & 16,67 & 2 & 2,60 & 4 & 4,04 & & 2.4635 & 0.0139 \\
\hline \multirow{2}{*}{$\begin{array}{c}\chi \text {-quadrat } \\
\chi \text {-quadrat } p \text {-value }\end{array}$} & \multicolumn{2}{|c|}{6.4588} & \multirow{2}{*}{\multicolumn{7}{|c|}{$\begin{array}{l}\text { MS - micro and small sized enterprises } \\
\text { ME - medium sized enterprises }\end{array}$}} \\
\hline & \multicolumn{2}{|c|}{0.0396} & & & & & & & \\
\hline
\end{tabular}

(Source: own data collection)

From the enterprises' sized point of view, it is obvious that the small companies use a participative management style the most, followed by medium-sized companies. This style is the least used in microbusinesses. Research showed that more than 16\% of entrepreneurs in micro-enterprises, who promote the concept of CSR in their practice, do not use a participatory management style. Results noted significant differences in responses in terms of company size, so hypothesis H4b was accepted. 
INTERNATIONAL JOURNAL OF ENTREPRENEURIAL KNOWLEDGE

Issue 1, volume 9, ISSN 2336-2960 (Online)

www.ijek.org

Table 9 "Our employees strive to improve their performance and competition among them prevails." - the structure of answers depending on the country

\begin{tabular}{|c|c|c|c|c|c|c|c|c|c|c|}
\hline & \multicolumn{2}{|c|}{ CZ 81} & \multicolumn{2}{|c|}{ SK 80} & \multicolumn{2}{|c|}{ PL 111} & \multicolumn{2}{|c|}{ HU 147} & \multirow{2}{*}{ Z-score } & \multirow{2}{*}{$\begin{array}{l}\text { Z-score } \\
\text { p-value }\end{array}$} \\
\hline & No. & $\%$ & No. & $\%$ & No. & $\%$ & No. & $\%$ & & \\
\hline strongly agree + agree & 50 & 61,73 & 48 & 60,00 & 61 & 54,95 & 108 & 73,47 & $\mathrm{CZ} / \mathrm{SK}$ & 0.8289 \\
\hline disinterested & 22 & 27,16 & 20 & 25,00 & 34 & 30,63 & 30 & 20,41 & $\mathrm{CZ} / \mathrm{PL}$ & 0.3472 \\
\hline $\begin{array}{c}\text { disagree }+ \text { strongly } \\
\text { disagree }\end{array}$ & 9 & 11,11 & 12 & 15,00 & 16 & 14,41 & 9 & 6,12 & $\mathrm{CZ} / \mathrm{HU} \quad-1.8395$ & 0.0658 \\
\hline$\chi$-quadrat & \multicolumn{2}{|c|}{12,0369} & & & & & \multirow{2}{*}{\multicolumn{2}{|c|}{$\begin{array}{l}\text { CZ - Czech Republic } \\
\text { SK - Slovak Republic }\end{array}$}} & \multirow{2}{*}{\multicolumn{2}{|c|}{$\begin{array}{l}\text { PL }- \text { Poland } \\
\text { HU }- \text { Hungary } \\
a=0.05\end{array}$}} \\
\hline$\chi$-quadrat p-value & \multicolumn{2}{|c|}{0,06115} & & & & & & & & \\
\hline
\end{tabular}

(Source: own data collection)

From the V4 countries point of view, it was not recognized statistically significant differences in the statement that the company's employees strive to improve their performance and competition prevails among them. Polish entrepreneurs agree the least with this statement, while the most positive answers were recorded by Hungarian companies. The H5a hypothesis was rejected.

Table 10 "Our employees strive to improve their performance and competition among them prevails." - the structure of answers depending on the size of the company

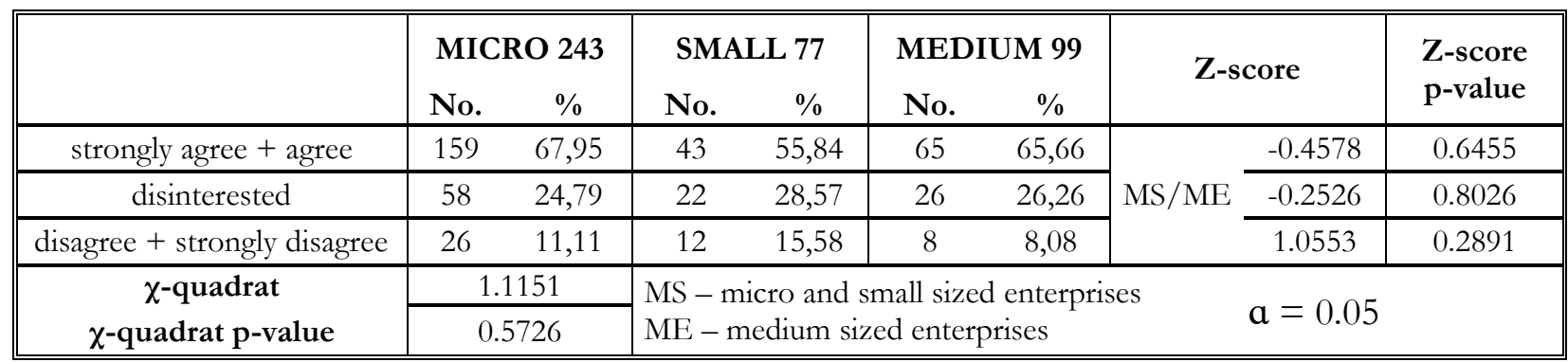

(Source: own data collection)

In the case of the company size, the least positive answers were observed in the segment of small businesses. Medium-sized companies had the lowest level of dissenting responses in this context compared to smaller companies. As the statistical calculations did not show significant differences in the claims, the H5b hypothesis was rejected.

Comparing the results with other studies, it could be confirmed that more than $95 \%$ of entrepreneurs implementing the CSR concept into management practice agreed with the statement that managers should regularly evaluate the performance of employees and motivate them to innovate work procedures. As it was pointed out by Liu et al. (2020), the implementation of CSR increases the commitment of employees to work process innovation.

The results of the study further showed that $2 / 3$ of employees in CSR active companies strive to increase work performance and competitiveness in the employee team. This allows expressing a certain association with the results of Galvas (2016), Wang et al. (2020), and Nazir \& Ul Islam (2020), which proof an increasing interest in employees and thus increase their loyalty to employers. Flammer \& Luo (2017) also note the positive influence of CSR implementation in companies on increasing employee performance and behavior, or as it is mention by Breger et al. (2020) on their motivation to work more. 


\section{INTERNATIONAL JOURNAL OF ENTREPRENEURIAL KNOWLEDGE}

Issue 1, volume 9, ISSN 2336-2960 (Online)

www.ijek.org

Involvement of employees in the decision-making process, e.g. by knowing employee's opinion on the object of decision-making, from the point of view of psychology, has a significant influence on loyalty and involvement towards the company (Galvas, 2016; Stojanovic et al., 2020; Ali et al., 2020; Jia et al. 2019). In this context, the research showed that the participatory management style is the most applied by Slovak entrepreneurs - this could reflect the fact that Slovak companies have the most active employees in the overall involvement in the company's activities - innovation and healthy competition between colleagues. But, on the other hand, Slovak entrepreneurs perceive employee involvement as the second-lowest compared to the others researched countries where the Hungarian segment is the leader. In the terms of company size, significant negative differences can also be seen in the comparison - almost 91\% of small companies are implemented participatory management style in their practice, but on the other hand in case of involvement only $56 \%$ of this segment agrees with increasing of employee performance.

According to Vveinhardt \& Sroka (2020), socially responsible organizations have lower employee turnover and arouse satisfaction and loyalty (Gorgenyi-Hegyes \& Fekete Farkas, 2019). The results found that the size of the company plays an important role in this case. The findings highlight that the bigger company is the higher turnover of employees is in the company (from the point of view of managers / owners).

\section{CONCLUSIONS}

The aim of the article was to find out the entrepreneurs' perception of CSR implementation into their business practice, to employees and thus to expand the knowledge by comparing this perception from the small and medium-sized enterprises in V4 countries. In some cases, significant differences were confirmed.

The results showed that small and medium-sized enterprises in V4 countries applying CSR to management practice, consider human capital as the most important without significant differences between countries and company size. The issue of measuring performance and the subsequent motivation of employees is very desirable and used by entrepreneurs. On average $98 \%$ of entrepreneurs, in each type of business size, consider performance measurement and motivation as very important, which is reflected in increasing performance, "healthy" inter-employee competition, or reducing employee turnover. From the fluctuation point of view, the lowest fluctuation was recorded among Hungarian entrepreneurs and the highest fluctuation was in Poland. The results showed that employee turnover differs significantly in the classification of the companies by size - if the company is larger the employee turnover is higher.

In the case of participatory management implementing by enterprise management, thus involves employees in the decision-making process, it was noticed significant differences between countries. Up to $90 \%$ of Slovak entrepreneurs involved in CSR activities apply a participatory management style. On the contrary, the least rate of implementation is recorded by Hungarian companies, only $69 \%$. In terms of size comparison, small enterprises, followed by medium-sized enterprises, use the participatory management style the most in the V4 countries, and micro-enterprises use this style the least. Even in this area, there are statistically significant deviations.

Looking at answers to the question of whether employees of companies are trying to increase performance and "healthy" competition prevails among them, it was found, despite several negative values, that Hungarian entrepreneurs agree with this statement - almost $74 \%$ of managers agree that their employees try to increase performance and "healthy" competition prevails among them. On the contrary, the lowest percentage of agreement $(55 \%)$ is in Polish companies. 


\section{INTERNATIONAL JOURNAL OF ENTREPRENEURIAL KNOWLEDGE}

Issue 1, volume 9, ISSN 2336-2960 (Online)

www.ijek.org

The limitation of this article is a statistical comparison of the perception of human capital only at the level of entrepreneurs implementing CSR in their companies. Comparing these results with entrepreneurs who do not implement CSR in their managerial practice can expand the knowledge and regard whether the implementation of the CSR concept in small and medium enterprises in the V4 countries has a positive or negative impact on human resources. The future studies of the authors will deal with the comparison of these results in the context of entrepreneurs who do not implement the concept of CSR. Another limitation factor of the study is following from the fact, that the study is focused only on the V4 countries, therefore it can not be stated that the results are generalizable. Despite mentioned limitations, this study can be seen as a starting base for future research on a larger sample with different countries in the world which do not have a comparable business environment. Future comparisons between companies could highlight better knowledge.

The results of the paper may be interesting for organizations that aim is to promote or implement CSR in the researched countries. The findings of the study can further help other entrepreneurs to consider the benefits of being socially responsible in the context of the working environment.

\section{REFERENCES}

Alhouti, S., Wright, S.A., \& Baker, T.L. (2021). Customers need to relate: The conditional warm glow effect of CSR on negative customer experiences. Journal of Business Research, 124, 240-253. https://doi.org/10.1016/j.jbusres.2020.11.047

Ali, H.Y., Asrar-ul-Haq, M., Amin, S., Noor, S., Haril-ul-Mahasbi, M., \& Aslam, M.K. (2020). Corporate social responsibility and employee performance: The mediating role of employee engagement in the manufacturing sector of Pakistan. Corporate Social Responsibility and Environmental Management, 27(6), 2908-2919. https://doi.org/10.1002/csr.2011

Bacinello, E., Tontini, G., \& Alberton, A. (2020). Influence of corporate social responsibility on sustainable practices of small and medium-sized enterprises: Implications on business performance. Corporate Social Responsibility and Environmental Management, 28(2), 776-785. https://doi.org/10.1002/csr.2087

Barakat, S. R., Isabella, G., Boaventura, J.M.G., \& Mazzon, J.A. (2016). The influence of corporate social responsibility on employee satisfaction. Management Decision, 54 (9), 2325-2339. https://doi.org/10.1108/MD-05-2016-0308

Bardos, K.S., Ertugrul, M., \& Gao, L. S. (2020). Corporate social responsibility, product market perception, and firm value. Journal of Corporate Finance, 62, art. No. 101588. https://doi.org/10.1016/j.jcorpfin.2020.101588

Belas J, C,era G, Dvorský J., \& Čepel M. (2020). Corporate social responsibility and sustainability issues of small- and medium-sized enterprises. Corporate Social Responsibility and Environmental Management, 28(2); 1-10. https://doi.org/10.1002/csr.2083

Bikefe, G., Zubairu, U., Araga, S., Maitala, F., Ediuku, E., \& Anyebe, D. (2020). Corporate Social Responsibility (CSR) by small and medium enterprises (SMEs): a systematic review. Small Business International Review, 4(1), 16-33. https://doi.org/10.26784/sbir.v4i1.243

Boccia, F., Manzo, R.M., \& Covino, D. (2019). Consumer behavior and corporate social responsibility: An evaluation by a choice experiment. Corporate Social Responsibility and Environmental Management, 26(1), 97-105. https://doi.org/10.1002/csr.1661

Brieger, S.A., Anderer, S., Froehlich, A., Baero, A., \& Meynhardt, T. (2020). Too Much of a Good Thing? On the Relationship Between CSR and Employee Work Addiction. Journal of Business Ethics, 166(2), 311-329. https://doi.org/10.1007/s10551-019-04141-8

Caroll, A. B. (2016). Carroll's pyramid of CSR: taking another look. International Journal of Corporate Social Responsibility, 1(3). https://doi.org/10.1186/s40991-016-0004-6 


\section{INTERNATIONAL JOURNAL OF ENTREPRENEURIAL KNOWLEDGE}

Issue 1, volume 9, ISSN 2336-2960 (Online)

www.ijek.org

Chen, J., Liu, J., \& Qin, J. (2019). Corporate social responsibility and capacity selection. Transformations in Business \& Economics, 18 (3C(48C)), 530-545.

Chen, L.F., \& Khuangga, D.L. (2020). Configurational paths of employee reactions to corporate social responsibility: An organizational justice perspective. Corporate Social Responsibility and Environmental management. 28(1), 389-403. https://doi.org/10.1002/csr.2056

Chojnacka E., \& Wiśniewska J. (2017). Benefits of Corporate Social Responsibility Engagement in Companies: The Case of Poland. Journal of Management and Business Administration, Central Europe, 24(4), 25-48. https://doi.org/10.7206/jmba.ce.2450-7814.181

Dayanandan, A., Donker, H., \& Nofsinger, J. (2018). Corporate goodness and profit warnings. Review of Quantitative Finance and Accounting, 51 (2), 553-573. https://doi.org/10.1007/s11156-017-0680-7

Du, S., Bhattacharya, C.B, \& Sen, S. (2010). Maximizing business returns to corporate social responsibility (CSR): The role of CSR communication. International Journal of Management Reviews. 12(1), 8-19. https://doi.org/10.1111/j.1468-2370.2009.00276.x

European Union. (2011). Communication from the Commission to the European Parliament, the Council, the European Economic and Social Committee and the Committee of the Regions - A renewed EU Strategy for Corporate Social Responsibility 2011-2014.

Farrukh, M., Sajid, M., Lee, J.W.C., \& Shahzad, I.A. (2019). The perception of corporate social responsibility and employee engagement: Examining the underlying mechanism. Corporate Social Responsibility and Environmental Management, 27(2), 760-768. https://doi.org/10.1002/csr.1842

Gelbman, U. (2010). Establishing Strategic CSR in SMEs: an Austrian CSR Quality Seal to Substantiate the Strategic CSR Performance. Sustainable Development, 18 (2), 90-98. https://doi.org/10.1002/sd.448

Glavas, A. (2016). Corporate Social Responsibility and Employee Engagement: Enabling Employees to Employ More of Their Whole Selves at Work. Frontiers in psychology, 7, Art. No. 796. https://doi.org/10.3389/fpsyg.2016.00796

Godfrey, A., Azigwe, J.B., \& Awuni, A.R. (2016). Business ethics and corporate social responsibility for business success and growth. European Journal of Business and Innovation Research, 4 (6), 26-42.

Gorgenyi-Hegyes, M., \& Fekete-Farkas, M. (2019). Internal CSR as a strategic management tool in reduction of labour shortages. Polish Journal of Management Studies, 19(2), 167-181. https://doi.org/10.17512/pjms.2019.19.2.14

Habek, P. (2017). CSR Reporting Practices in Visegrad Group Countries and the Quality of Disclosure. Sustainability, 9(12). 2322. https://doi.org/10.3390/su9122322

Hadj, T. B., Omri, A., \& Al-Tit, A. (2020). Mediation role of responsible innovation between CSR strategy and competitive advantage: Empirical evidence for the case of Saudi Arabia enterprises. Management Science Letters, 10(4), 747-762. https://doi.org/10.5267/j.msl.2019.10.022

Jia, Y., Yan, J., Liu, T., \& Huang, J. (2019). How Does Internal and External CSR Affect Employees' Work Engagement? Exploring Multiple Mediation Mechanisms and Boundary Conditions. International Journal of Environmental Research and Public Health, 16(14), art. No. 2476. https://doi.org/10.3390/ijerph16142476

Jorge, M.L.; Madueno, J.H., Sancho, M.P.L., \& Martinez-Martinez, D. (2016). Development of corporate social responsibility in small and medium-sized enterprises and its nexus with quality management. $\begin{array}{llllll}\text { Cogent Business } \& \text { Management, } & \text { art. } & \text { No. } 28569 .\end{array}$ https://doi.org/10.1080/23311975.2016.1228569

Kang, J.Y., Slaten, T., \& Choi, W. J. (2021). Felt betrayed or resisted? The impact of pre-crisis corporate social responsibility reputation on post-crisis consumer reactions and retaliatory behavioral intentions. Corporate Social Responsibility and Environmental Management, 28(1), https://doi.org/511524. 10.1002/csr.2067

Kljucnikov, A., Belas, J., Kozubikova, L., \& Pasekova, P. (2016). The Entrepreneurial Perception of SME Business Environment Quality in the Czech Republic. Journal of Competitiveness, 8 (1), 66-78. https://doi.org/10.7441/joc.2016.01.05 


\section{INTERNATIONAL JOURNAL OF ENTREPRENEURIAL KNOWLEDGE}

Issue 1, volume 9, ISSN 2336-2960 (Online)

www.ijek.org

Lazanyi, K., Feher-Polgar, P., \& Vida, I. (2020). Identification of the most important European productivity factors through the dimension reduction. Ekonomicko-manazerske spektrum, 14(1), 7786.

Lee, S.Y. (2016). How can companies succeed in forming CSR reputation? Corporate Communications, 21(4), 435-449. https://doi.org/10.1108/CCIJ-01-2016-0009

Li, Y.B., Zhang, G.Q., Wu, T.J., \& Peng, C.L. (2020) Employee's Corporate Social Responsibility Perception and Sustained Innovative Behavior: Based on the Psychological Identity of Employees. Sustainability, 12 (20), art. No. 8604. https://doi.org/10.3390/su12208604

Liu, B.H., Sun, P.Y., \& Zeng, Y.L. (2020). Employee-related corporate social responsibilities and corporate innovation: Evidence from China. International Review of Economics \& Finance, 70, 357-372. https://doi.org/10.1016/j.iref.2020.07.008

Lu, J., Ren, L., Zhang, C., Wang, C., Shadid, Z., \& Streimikis, J. (2020). The influence of a firm's CSR initiatives on brand loyalty and brand image. Journal of Competitiveness, 12(2), 106-124. https://doi.org/106-124. 10.7441/joc.2020.02.07

Lušňáková, Z., Lenčéšová, S. \& Šajbidorová M. (2019). Growing role of CSR activities in the area of human resources management and its evaluation using quantitative methods. Mathematics in Education, Research and Applications, 5(1), 16-29. https://doi.org/10.15414/meraa.2019.05.01.16-29

Marques Lourenço, M. S. \& de Sousa-Filho, J. M. (2020) 'Determinants of Corporate Social Responsibility Practices: Institutional Pressure or Strategic Opportunity? Brazilian Journal of Management / Revista de Administração da UFSM, 13(3), 535-553.

Meloun, M. \& Militký, J. (2012). Handbook of statistical processing of dates. Karolinum.

Nagypál, C.N. (2014). Corporate social responsibility of Hungarian SMEs with good environmental practices. Journal for East European Management Studies, 19(3), 327-347. https://doi.org/10.5771/0949-6181-2014-3-327

Nazir, O., \& Ul Islam, J. (2020). Effect of CSR activities on meaningfulness, compassion, and employee engagement: A sense-making theoretical approach. International Journal of Hospitality Management, 90, art. No. 102630. https://doi.org/10.1016/j.ijhm.2020.102630

OECD. (2001). Corporate responsibility: private initiatives and public goals. In Mexico Hungary Korea.

Reicher, Z.R. (2019). Opportunities for small and medium sized enterprises in the field of corporate social responsibility. Ekonomicko-manazerske Spektrum, 13(1), 26-37.

Reichert, B.E., \& Sohn, M. (2021). How corporate charitable giving reduces the cost of formal controls. Journal of Business Ethics, early access. https://doi.org/10.1007/s10551-020-04695-y

Rocha, E. A. G. (2012). The Impact of the Business Environment on the Size of the Micro, Small and Medium Enterprise Sector; Preliminary Findings from a Cross-Country Comparison. Procedia Economics and Finance. 4, 335-349. https://doi.org/10.1016/S2212-5671(12)00348-6

Rupp, D.E., Shao, R.D., Skarlicki, D.P., Paddock, E.L., Kim, T.Y., \& Nadisic, T. (2018). Corporate social responsibility and employee engagement: The moderating role for CSR-specific relative autonomy and individualism. Journal of Organizational Behaviour, 39(5), 559-579. https://doi.org/10.1002/job.2282

Slabá, M. (2020). Corporate social responsibility: Motivation, perception, and activities among SMEs in the czech republic: Acces la success. Calitatea, 21(177), 68-73.

Stojanovic, A., Milosevic, I., Arsic, S., Urosevic, S., \& Mihajlovic, I. (2020). Corporate social responsibility as a determinant of employee loyalty and business performance. Journal of Competitiveness, 12(2), 149166. https://doi.org/10.7441/joc.2020.02.09

Thao, L.H.H., Anh, D.N.P., \& Velencei, J. (2019). Measuring corporate social performance. Serbian Journal of Management, 14 (1), 193-204. https://doi.org/10.5937/sjm14-18009

Vveinhardt, J., Sroka, W. (2020). Mobbing and corporate social responsibility: does the status of the organisation guarantee employee wellbeing and intentions to stay in the job? Oeconomica Copernicana, 11(4), 743-778. https://doi.org/10.24136/oc.2020.030 
INTERNATIONAL JOURNAL OF ENTREPRENEURIAL KNOWLEDGE

Issue 1, volume 9, ISSN 2336-2960 (Online)

www.ijek.org

Walker M, Hills S, \& Heere B. (2017).Evaluating a socially responsible employment program: Beneficiary impacts and stakeholder perceptions. Journal of Business Ethics, 143(1), 53-70. https://doi.org/10.1007/s10551-015-2801-3

Yumei, H., Iqbal, W., Nurunnabi, M. Abbas, M. Jingde, W., \& Chaudhry, I.S. (2021). Nexus between corporate social responsibility and firm's perceived performance: evidence from SME sector of developing economies. Environmental Science and Pollution Research,28(2), 2132-2145. https://doi.org/10.1007/s11356-020-10415-w

Zelazna, A., Bojar, E., \& Bojar, M. (2020). Corporate social responsibility towards the environment in Lublin region, Poland: A comparative study of 2009 and 2019. Sustainability (Switzerland), 12(11), art. No. 4463. https://doi.org/10.3390/su12114463

Zeng, T., Audrain-Pontevia, A.F., \& Durif, F. (2020). Does corporate social responsibility affect consumer boycotts? A cost-benefit approach. Corporate Social Responsibility and Environmental Management, 28 (2), 796-807. https://doi.org/10.1002/csr.2089

\section{ACKNOWLEDGMENT}

This paper is supported by Tomas Bata University in Zlin through; IGA/FaME/2021/005. Significant factors in the sustainability of economic growth with a focus on the SME segment.

\section{BRIEF DESCRIPTION OF AUTHOR/AUTHORS:}

\section{Zdenko Metzker}

ORCID ID: https://orcid.org/0000-0002-6962-2428

Ph.D. student in Center of Applied Economics Research, Faculty of Management and Economics Thomas Bata University in Zlin, Mostní 5139, Zlín, Czech Republic, e-mail: metzker@utb.cz. His research field is focused on Corporate social responsibility in small and medium-sized enterprises segment.

\section{Ing. Katarina Zvarikova, PhD.}

ORCID ID: https://orcid.org/0000-0001-5278-9275

Assistant prof. at the Department of Economics, Faculty of Operation and Economics of Transport and Communications, Univerzitna 8215/1, University of Zilina. Her research activities are focused mainly on applying methods in financial management and decision-making process of companies, risk quantification and analysis, quantitative mathematical-statistical methods in the company's financial management. 